\title{
Honey sugars profile of stingless bee Tetragonula laeviceps (Hymenoptera: Meliponinae)
}

\author{
ALI AGUS ${ }^{1}$, AGUSSALIM ${ }^{1}$, MUHAMAD SAHLAN ${ }^{2}$, ARDO SABIR ${ }^{3, \bullet}$ \\ ${ }^{1}$ Department of Animal Nutrition and Feed Science, Faculty of Animal Science, Universitas Gadjah Mada. Jl. Fauna 3, Bulaksumur, Sleman 55281, \\ Yogyakarta, Indonesia \\ ${ }^{2}$ Department of Chemical Engineering, Faculty of Engineering, Universitas Indonesia. J1. Prof. Dr. Sumitro Djojohadikusumo, Kampus UI, Depok 16424, \\ West Java, Indonesia \\ ${ }^{3}$ Department of Conservative Dentistry, Faculty of Dentistry, Universitas Hasanuddin. Jl. Perintis Kemerdekaan Km 10, Tamalanrea, Makassar 90245 , \\ South Sulawesi, Indonesia. Tel.: +62-411-586012, ’email: ardo.sabir@yahoo.com, aliagus@ugm.ac.id
}

Manuscript received: 11 October 2021. Revision accepted: 30 October 2021.

\begin{abstract}
Agus A, Agussalim, Sahlan M, Sabir A. 2021. Honey sugars profile of stingless bee Tetragonula laeviceps (Hymenoptera: Meliponinae). Biodiversitas 22: 5205-5210. Honey was a functional food to improve human health, but irresponsible people used this circumstance to make fake honey. This study aimed to evaluate the profile of the sugar of stingless bee honey [Tetragonula laeviceps (Smith, 1857)] from different geographical origins in Indonesia. Honey, three samples were directly collected from three other sources for meliponiculture of T. laeviceps in Indonesia: Sleman, Klaten, and Gunungkidul. The honey sugars profile was analyzed: glucose, fructose, sucrose, reducing sugar, the sum of fructose and glucose, glucose to moisture ratio, fructose to glucose ratio, and honey $\mathrm{pH}$. Glucose and fructose were analyzed by HPLC, sucrose by Luff Schoorl, reducing the sugar by Layne-Enyon, and $\mathrm{pH}$ by a $\mathrm{pH}$ meter. The current findings revealed that the geographical origins had a highly significant effect on glucose, fructose, the sum of fructose and glucose, glucose to moisture ratio, fructose to glucose ratio, and honey $\mathrm{pH}(\mathrm{P}<0.01)$ and significant effect on reducing sugar $(\mathrm{P}<0.05)$, but not on sucrose content. Thus, it can be concluded that the origins were affecting the honey sugars profile and honey from Sleman has the highest sugars content, followed by honey from Klaten and the lower was honey from Gunungkidul.
\end{abstract}

Keywords: Fructose, glucose, honey, nectar, sucrose

\section{INTRODUCTION}

In the world, about 500 species of stingless bees and more than 100 species have not been studied (Michener 2013), meanwhile in Indonesia for nearly 46 species have been identified (Kahono et al. 2018) and in Yogyakarta for about 7 species (Trianto and Purwanto 2020). For example, Tetragonula laeviceps (Smith, 1857) was found in Indonesia have natural habitats including tree's trunks, woods, sugar palm stalks, bamboo, and in the ground (Agus et al. 2019; Agussalim et al. 2019a, 2019b, 2020, 2021; Erwan et al. 2020, 2021; Sabir et al. 2021). Therefore, they could produce honey is lower, but propolis production is higher than honeybees from genus Apis (Agus et al. 2019; Agussalim et al. 2019a, 2019c, 2020, 2021). Honey is a sweet natural food made by honeybees (Apis genus) or stingless bees (Meliponini, Meliponinae) using nectar as their raw material that is obtained from plant flowers (floral nectar), secreted by plants living parts (extrafloral nectar), and secreted by plant-sucking insects (honeydew) (Thrasyvoulou et al. 2018; Agussalim 2020). Honey is produced by the bee workers and made it using nectar mixed with some enzymes (including diastase, invertase) and stored in the honeycomb for honeybees and in a honey pot for the stingless bees. Honey is mostly composed of sugars, protein (amino acids and enzymes), vitamins, organic acids, minerals, carotenoids, and secondary metabolites (Da Silva et al. 2016).
The honey physicochemical of several stingless bees from different countries have been studied (Souza et al. 2006; Guerrini et al. 2009; Suntiparapop et al. 2012; Biluca et al. 2016; Chuttong et al. 2016; Nordin et al. 2018; Ranneh et al. 2018; Villacrés-Granda et al. 2021) and stingless bee honey from Indonesia have also been studied (Agus et al. 2019; Agussalim et al. 2019b, 2019c, 2021; Sabir et al. 2021). Moreover, we have been found the sugar profile of honey from $T$. laeviceps origin from Indonesia: Sleman (Yogyakarta) with sweet flavor, from North Lombok (West Nusa Tenggara) and Klaten (Central Java) honey with a combination of sweet and a bit sour flavors (Agussalim et al. 2019a). However, the profile of the sugar of honey from other geographical origins in Indonesia has not been studied. Recently the demand for honey increased significantly because honey is the functional food to improve human health. Still, irresponsible people use this circumstance to make a fraud honey (manipulation of honey) using sweeteners such cane and beet sugars and also the bees are fed using a syrup. The new finding reported that stingless bee honey contains disaccharide trehalulose as the main component ranges from 13 to $44 \mathrm{~g}$ per $100 \mathrm{~g}$ from T. carbonaria, T. hockingsi, Geniotrigona thoracica, Heterotrigona itama, and Tetragonisca angustula (Fletcher et al. 2020). The honey chemical composition is influenced by nectar source from plants, bee species, origins, environmental conditions (including temperature and humidity), postharvest processing (manipulation, heater, 
and weather exposure), and storage time (Chanchao 2013; Escuredo et al. 2013; Tornuk et al. 2013; Juan-Borrás et al. 2014; Biluca et al. 2016; Da Silva et al. 2016; Nordin et al. 2018; Agus et al. 2019; Agussalim, 2020; Agussalim et al. 2019a, 2021; Villacrés-Granda et al. 2021). Therefore, this study aimed to evaluate the profile of the sugar of honey from $T$. laeviceps from different origins in Indonesia.

\section{MATERIALS AND METHODS}

\section{Study area}

Honey $T$. laeviceps was used in this study was obtained from three geographical origins in Indonesia consisting of Sleman (Faculty of Animal Science, Universitas Gadjah Mada), Klaten (Glodogan Village), and Gunungkidul (Katongan Village). Honey, each location was collected three samples of honey and they have different flavors were sweet honey (Sleman), bitter flavor honey (Gunungkidul), and sweet with a bit sour honey (Klaten).

\section{Procedures}

Analysis of fructose and glucose contents

High-pressure liquid chromatography (HPLC) was used to analyze the honey fructose and glucose contents (Agussalim et al. 2019a). Aquadest $5 \mathrm{~mL}$ was used to combine $0.11 \mathrm{~g}$ of honey, subsequently extracted using an ultrasonic sonicator (15 minutes). The samples were then vortexed for two minutes before being centrifuged for five minutes. Afterward, the pellet was extracted three times, and the supernatant was moved to a $25 \mathrm{~mL}$ Erlenmeyer flask and centrifuged for five minutes. It was filtered with Millex $(0.45 \mu \mathrm{M})$ and $20 \mu \mathrm{L}$ was to the HPLC column. The concentrations of fructose and glucose standards consist of $12.5,25,100,500$, and $1,000 \mathrm{ppm}$. Standard curve to calculate the honey glucose content was $\mathrm{Y}=36261 \mathrm{x}-$ 20829 with $\mathrm{R} 2=0.9999$ and $\mathrm{Y}=34632 \mathrm{x}+92303$ with $\mathrm{R} 2$ $=0.9998$ for fructose content.

\section{Analysis of sucrose content}

The Luff Schoorl method was used to analyze honey sucrose content (AOAC 2005), consisting of two steps (before and after inversions). Before inversion, $2 \mathrm{~g}$ of honey was added to the Erlenmeyer flask $(50 \mathrm{~mL})$ containing aquadest and then homogenized. The $5 \mathrm{~mL}$ sample was mixed with $25 \mathrm{~mL}$ of Luff Schoorl solution and two boiling stones, then chilled. Afterward, the solution was heated using a water bath $\left(60^{\circ} \mathrm{C}\right)$ for ten minutes and cooled quickly before adding $15 \mathrm{~mL}$ of $\mathrm{KI}(20 \%)$ and 25 $\mathrm{mL}$ of $\mathrm{H}_{2} \mathrm{SO}_{4}(26.5 \%)$ and then titrated by $\mathrm{Na}_{2} \mathrm{~S}_{2} \mathrm{O}_{3} 0.2 \mathrm{~N}$ (standardized) and followed by starch (2 to $3 \mathrm{~mL}$ ) around the titration endpoint. Total sugar amount before inversion was counted by equation 1: Sugar with $\mathrm{N} \mathrm{Na}_{2} \mathrm{~S}_{2} \mathrm{O}_{3}(0.2 \mathrm{~N})$ $(\mathrm{mg})=((\mathrm{A}+\mathrm{C}) \times \mathrm{B})-\mathrm{A}$, where $\mathrm{A}$ : mg sugar (small); $\mathrm{B}$ : mg sugar (big); $\mathrm{C}$ : titration difference decimal). Also, equation 2: Total sugar $(\%)=\left(\right.$ Sugar with $\mathrm{N} \mathrm{Na}_{2} \mathrm{~S}_{2} \mathrm{O}_{3}(0.2$ $\mathrm{N}) \times$ dilution factor $\times 100 \%) /$ sample weight $(\mathrm{g})$ ).

After inversion, $10 \mathrm{~mL}$ of filtrate and $5 \mathrm{~mL} \mathrm{HCl}$ $(6.76 \%)$ were transferred to a $50 \mathrm{~mL}$ Erlenmeyer flask and homogenizing. Afterward, the solution was then heated for ten minutes and quickly chilled to $20^{\circ} \mathrm{C}$ before adding a few drops of phenolphthalein indicator and neutralizing with $\mathrm{NaOH} 20 \%$ until red color appeared. Furthermore, the $\mathrm{HCl}(0.5 \mathrm{~N})$ solution was added dropwise until the red color dissipated, and then the solution was diluted to the desired concentration with aquadest. The $50 \mathrm{~mL}$ of samples were transferred to an Erlenmeyer flask, then filled with 25 $\mathrm{mL}$ of Luff Schoorl solution and two boiling stones. Afterward, the samples were chilled and heated for ten minutes in a water bath $\left(60^{\circ} \mathrm{C}\right)$. The solution was promptly chilled before adding $15 \mathrm{~mL}$ of $\mathrm{KI}(20 \%)$ and $25 \mathrm{~mL}$ of $\mathrm{H}_{2} \mathrm{SO}_{4}(26.5 \%)$, and then titrated with $\mathrm{Na}_{2} \mathrm{~S}_{2} \mathrm{O}_{3} 0.2 \mathrm{~N}$ (standardized) and 2 to $3 \mathrm{~mL}$ of starch towards the titration's endpoint. Equations 1 and 2 were used to calculate total sugar after inversion. Equations 3 and 4 were used to calculate the total sugar (\%): Equation 3: Sugar total $(\% \mathrm{w} / \mathrm{v})=$ sugar content after inversion - before inversion; Equation 4: Sucrose content $(\% \mathrm{w} / \mathrm{v})=$ sugar total $(\% \mathrm{w} / \mathrm{v}) \times 0.95$.

\section{Analysis of reducing sugar}

The Layne-Enyon method was used to analysis of honey-reducing sugar (AOAC 2005). First, approximately $2.6 \mathrm{~g}$ of honey was put into a volumetric flask $(500 \mathrm{~mL})$. Afterward, $5 \mathrm{~mL}$ of Fehling's solutions (A and B) were mixed with $7.0 \mathrm{~mL}$ of water and $15.0 \mathrm{~mL}$ of honey solution, then homogenized and heated. Afterward, $1.0 \mathrm{~mL}$ of methylene blue $(0.2 \%)$ was added and then titrated by honey solution until decolorized.

\section{Data analysis}

The honey sugars profile was analyzed by one-way analysis of variance using SPSS release 23, followed by honestly significant difference test, which was significant at $\mathrm{P}<0.01$ level.

\section{RESULTS AND DISCUSSION}

\section{Results}

The current findings revealed that the difference of geographical origins was a highly significant effect on the glucose and sucrose contents, the sum of fructose and glucose $(\mathrm{F}+\mathrm{G})$, glucose to moisture ratio $(\mathrm{G} / \mathrm{M})$, fructose to glucose ratio $(\mathrm{F} / \mathrm{G})$, and $\mathrm{pH}$ of honey from $T$. laeviceps $(\mathrm{P}<0.01)$ and significant effect on the reducing sugar $(\mathrm{P}<0.05)$, but not on the sucrose content (Figures 1 and 2). The honey glucose content from Sleman $(17.87 \%$ w/w) was similar to the glucose content of honey from Gunungkidul $(16.22 \%$ w/w), but both were higher than the glucose content of honey from Klaten $(11.36 \% \mathrm{w} / \mathrm{w})$. The fructose content of honey from Sleman $(19.67 \% \mathrm{w} / \mathrm{w})$ was highest than the fructose content of honey from Klaten $(15.17 \% \mathrm{w} / \mathrm{w})$ and the lowest of honey sucrose content from Gunungkidul $(4.82 \% \mathrm{w} / \mathrm{w})$. The F+G of honey from Klaten $(26.53 \% \mathrm{w} / \mathrm{w})$ was similar with $\mathrm{F}+\mathrm{G}$ of honey from Gunungkidul (21.04\% w/w), but both were lower than F+G of honey from Sleman $(37.54 \% \mathrm{w} / \mathrm{w})$. 


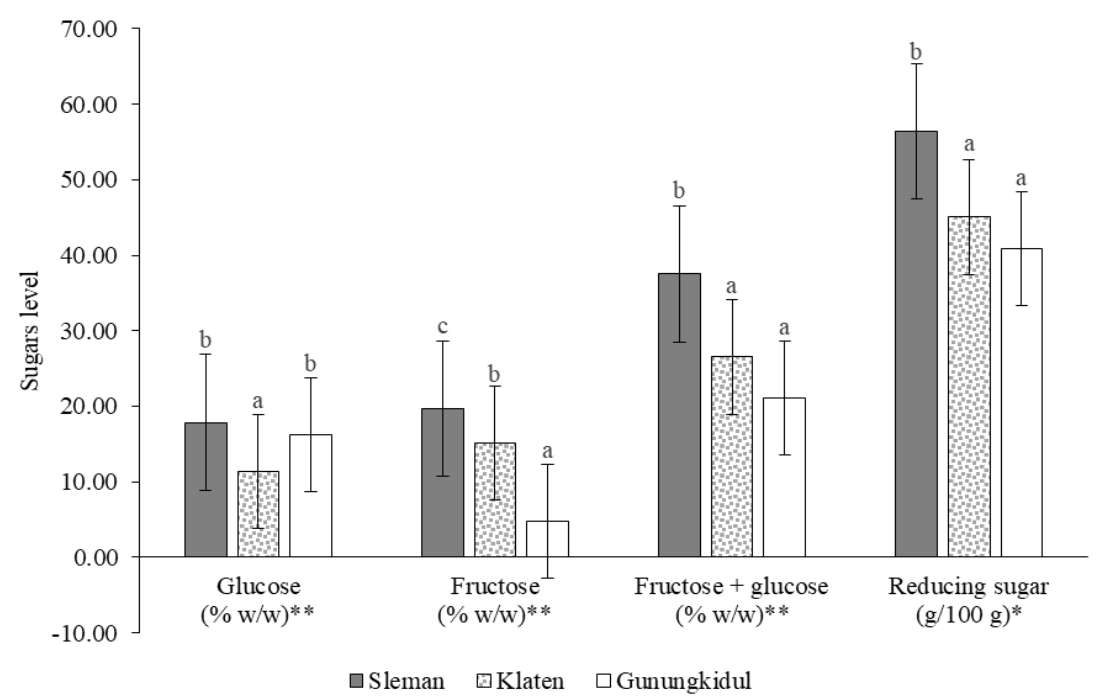

Figure 1. The glucose, fructose, fructose + glucose, and reducing sugar of Tetragonula laeviceps honey $(* *$ significant at $\mathrm{P}<0.01$ and *significant at $\mathrm{P}<0.05$ )

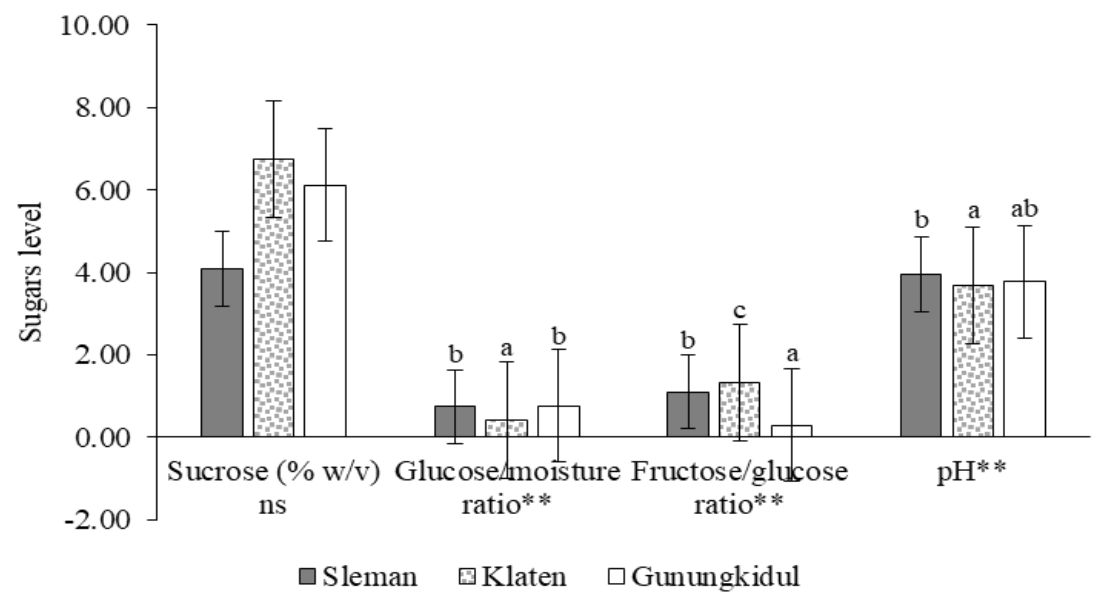

Figure 2. The sucrose, glucose/moisture ratio, fructose/glucose ratio, and $\mathrm{pH}$ of Tetragonula laeviceps honey $(* *$ significant at $\mathrm{P}<0.01$, *significant at $\mathrm{P}<0.05$, and $n s$ was not significant)

Reducing the sugar content of honey from Klaten (45.04 $\mathrm{g} / 100 \mathrm{~g})$ was similar to lowering the sugar of honey from Gunungkidul (40.90 g/100 g). Still, both were lower than reducing sugar of honey from Sleman $(56.40 \mathrm{~g} / 100 \mathrm{~g})$. Sucrose content of honey for all geographical origins were similar, where in Sleman $(4.08 \% \mathrm{w} / \mathrm{v})$, Klaten $(6.74 \% \mathrm{w} / \mathrm{v})$, and Gunungkidul $(6.11 \% \mathrm{w} / \mathrm{v})$. The glucose to moisture ratio (G/M) of honey from Sleman (0.74) was similar to $\mathrm{G} / \mathrm{M}$ of honey from Gunungkidul (0.77), but both were higher than the $\mathrm{G} / \mathrm{M}$ of honey from Klaten $(0.42)$. The fructose to glucose ratio $(\mathrm{F} / \mathrm{G})$ of honey from Klaten (1.34) was highest than $\mathrm{F} / \mathrm{G}$ of honey from Sleman (1.10), but the lowest of F/G honey from Gunungkidul (0.30). The $\mathrm{pH}$ of honey from Sleman (3.95) was higher than the $\mathrm{pH}$ of honey from Klaten (3.68) but did not differ from the $\mathrm{pH}$ of honey from Gunungkidul (3.78). However $\mathrm{pH}$ of honey from Klaten and Gunungkidul, on the other hand, did not vary.

\section{Discussion}

The sugars in honey are roles for energy source, hygroscopicity, viscosity, and granulation which was composed of monosaccharides for about $75 \%$ of the total sugars, followed by disaccharides 10 to $15 \%$ and other sugars for Apis mellifera honey (Kamal and Klein 2011; Da Silva et al. 2016). The type of sugars present in honey has been studied are fructose, sucrose, glucose, trehalose, rhamnose, nigerobiose, maltose, isomaltose, maltotriose, maltotetraose, melezitose, maltulose, nigerose, melibiose, raffinose, palatinose, and erlose for A. mellifera honey (De La Fuente et al. 2011; Da Silva et al. 2016). Meanwhile, in stingless bees, honey also has been studied, such as sucrose, glucose, fructose (Biluca et al. 2016; Chuttong et al. 2016; Nordin et al. 2018; Agussalim et al. 2019a; Villacrés-Granda et al. 2021), maltose (Chuttong et al. 2016; Nordin et al. 2018), and trehalulose (Fletcher et al. 2020). 
The honey sugars profile was influenced by geographical origin related to nectar sources from plants and the different environmental conditions, including temperature and humidity (Da Silva et al. 2016; Biluca et al. 2016; Agussalim et al. 2019a; Villacrés-Granda et al. 2021). In addition, it is also affected by postharvest honey processing (heater, weather exposure, and manipulation) and storage time (Chanchao 2013; Tornuk et al. 2013; Escuredo et al. 2014; Juan-Borrás et al. 2014; Da Silva et al. 2016). However, in our study, we use fresh honey and has not been processed. Therefore, the environment's high temperature and low humidity will impact plant flowers to produce low moisture nectar but high sugar content. Furthermore, the low temperature and high humidity affect the flowers plant to produce nectar with high moisture but low sugar content (Agussalim 2020). The plants as the source of nectar in our study from Sleman consist of banana, rambutan, canarium, tamarind, matoa, cattapa, and caimito. In Klaten consist of coconut, mango, rambutan, and banana, while in Gunungkidul consists of calliandra, Mexican creeper, banana, mango, and white albizia (Agus et al. 2019).

Codex Alimentarius has not regulated all sugars content of honey from stingless bees for an international standard to evaluate the honey quality (Codex Alimentarius 2001). In Indonesia, the standard has been regulated for stingless bee honey, such as reducing sugar is a minimum of $65 \% \mathrm{w} / \mathrm{w}$ and sucrose content is a maximum of $5 \%$ w/w (SNI 2018). However, in honeybee $A$. mellifera has been regulated the standard quality such as sum F+G is a minimum of $60 \mathrm{~g} / 100 \mathrm{~g}$ (blossom honey) and a minimum of $45 \mathrm{~g} / 100 \mathrm{~g}$ (honeydew), sucrose content is a maximum of $5 \mathrm{~g} / 100 \mathrm{~g}$ (both blossom honey and honeydew), reducing sugar is a minimum of 65 $\mathrm{g} / 100 \mathrm{~g}$ (both blossom honey and honeydew) (Bogdanov et al. 1999; Thrasyvoulou et al. 2018). However, the setting quality standard for stingless bees species has been reported by Souza et al. (2006). The glucose content of honey ranges from 21.9 to $35.7 \mathrm{~g} / 100 \mathrm{~g}$ but has not been used for an international standard.

The honey glucose content from $T$. laeviceps (Figure 1) was different from a previous study by Agussalim et al. (2019a) for a honey of $T$. laeviceps from different geographical origins in Indonesia (Sleman, Lombok, and Nglipar Gunungkidul) is ranging from 11.49 to $22.78 \%$ w/w. Furthermore, Villacrés-Granda et al. (2021) reported that the honey glucose content from twelve species of stingless bees from different Ecuador regions ranges from 26.00 to 38.26 $\mathrm{g} / 100 \mathrm{~g}$. The glucose content of honey was obtained from 67 stingless bee species ranging from 4.9 to $31.5 \mathrm{~g} / 100 \mathrm{~g}$ (Nordin et al. 2018). Biluca et al. (2016) reported that the glucose content of honey from ten species of stingless bees was collected from four different geographical origins in Santa Catarina, Brazil is ranging from 8.21 to $31.3 \% \mathrm{w} / \mathrm{w}$. Furthermore, the honey glucose content from eleven stingless bees from Thailand runs 4.9 to $26 \mathrm{~g} / 100 \mathrm{~g}$ (Chuttong et al. 2016).

Escuredo et al. (2014) explained that the fructose is dominant sugar in almost all of the honey from $A$. mellifera from the various plant as the nectar source to produce honey such as bramble, eucalyptus, chestnut, acacia, sunflower, lime, and honeydew, except in rape honey (Brassica napus). Rape honey is lower in fructose content but higher in glucose content that impacts the rapid crystallization. This condition is found in honey from Gunungkidul (Figure 1), where the fructose content was lower than glucose content but has not been crystallized. However, it has been stored for about 2 years. The fructose content of $T$. laeviceps honey (Figure 1) was different from a previous study by Agussalim et al. (2019a) for a honey of $T$. laeviceps from different geographical origins in Indonesia (Sleman, Lombok, and Nglipar Gunungkidul) is ranging from 7.79 to $22.92 \%$ w/w. Furthermore, honey glucose content from twelve species of stingless bees from different regions in Ecuador ranges from 34.77 to $44.57 \mathrm{~g} / 100 \mathrm{~g}$ (Villacrés-Granda et al. 2021), 6 to $54.38 \mathrm{~g} / 100 \mathrm{~g}$ from 67 species of stingless bee (Nordin et al. 2018), 30.4 to $46.1 \%$ w/w from ten species of stingless bees (Meliponinae) from Santa Catarina, Brazil (Biluca et al. 2016), and 6.0 to $34.33 \mathrm{~g} / 100 \mathrm{~g}$ for honey from Thailand (Chuttong et al. 2016).

The sum F+G of honey from $A$. mellifera has been regulated by Codex Alimentarius (2001) to determine the honey quality is minimum of $65 \mathrm{~g} / 100 \mathrm{~g}$ (blossom honey) and a minimum of $45 \mathrm{~g} / 100 \mathrm{~g}$ (honeydew) (Bogdanov et al. 1999; Thrasyvoulou et al. 2018), however, for stingless bees honey has not been regulated. The sum $\mathrm{F}+\mathrm{G}$ depend on the glucose and fructose contents and their content in our study differed from previous research by Agussalim et al. (2019a) for honey from $T$. laeviceps from different geographical origins from Indonesia (Sleman, Lombok, and Nglipar Gunungkidul) is ranging from 30.57 to $43.16 \% \mathrm{w} / \mathrm{w}$. Furthermore, also was differ reported by Villacrés-Granda et al. (2021) for stingless bee honey from Ecuador is ranging from 65.05 to $80.59 \mathrm{~g} / 100$ $\mathrm{g}, 13$ to $59.61 \mathrm{~g} / 100 \mathrm{~g}$ for honey from 11 stingless bee species in Thailand (Chuttong et al. 2016), 54.8 to $70.4 \% \mathrm{w} / \mathrm{w}$ for honey from ten species of stingless bees (Meliponinae) from Santa Catarina, Brazil (Biluca et al. 2016).

Reducing sugar of honey from the stingless bee has been regulated by Indonesian standard to determine the honey quality is minimum of $65 \% \mathrm{w} / \mathrm{w}$ (SNI 2018) and reducing sugar of honey from $T$. laeviceps (Figure 2) was not accepted by Indonesian standard. However, honey from Apis mellifera has been regulated by Codex Alimentarius (2001) with the minimum reducing sugar being 65 for blossom honey and 60 for honeydew (Bogdanov et al. 1999; Thrasyvoulou et al. 2018). Reducing sugar of T. laeviceps honey (Figure 2) was different with previously reported by Agussalim et al. (2019a) is ranging from 44.07 to 60.14 for honey from $T$. laeviceps is origin from Indonesia (Sleman, Lombok, and Nglipar Gunungkidul), 62.62 to $82.63 \mathrm{~g} / 100 \mathrm{~g}$ from twelve species of stingless bees from different regions in Ecuador (VillacrésGranda et al. 2021), 12.5 to $75.7 \mathrm{~g} / 100 \mathrm{~g}$ from 67 species of stingless bee (Nordin et al. 2018), 48.6 to $70.5 \% \mathrm{w} / \mathrm{w}$ for honey from ten species of stingless bees (Meliponinae) from Santa Catarina, Brazil (Biluca et al. 2016).

The sucrose content of honey is one of the critical parameters to evaluate the honey maturity level, where honey is harvested early (immature honey). It suggests that sucrose has not yet been entirely converted into glucose and fructose. In addition, the sucrose content is used to identify or verify a fraud honey (adulteration and manipulate honey) and higher sucrose content may indicate the adulteration of honey using artificial sweeteners such as cane sugar, beet sugar, and honey 
produced by the bees were fed using cane sugar dilution or syrup (Escuredo et al. 2013; Puscas et al. 2013; Tornuk et al. 2013; Da Silva et al. 2016; Agussalim, 2020). The Indonesian standard has regulated the sucrose content of stingless bee honey exceeding $5 \% \mathrm{w} / \mathrm{w}$ to evaluate the honey quality and verify the adulteration of honey. The honey sucrose content of T. laeviceps (Figure 2) is accepted by Indonesian standard for honey from Sleman but honey Klaten and Gunungkidul is not acceptable. The honey sucrose content from $T$. laeviceps (Figure 2) differed with the previous study by Agussalim et al. (2019a) for T. laeviceps honey from the different geographical origins from Indonesia (Sleman, Lombok, and Nglipar Gunungkidul) is ranging from 2.56 to $4.49 \% \mathrm{w} / \mathrm{w}$ (Agussalim et al. 2019a). In addition, was differ with reported by Villacrés-Granda et al. (2021) 2.63 to 5.14 from twelve species of stingless bees from different regions in Ecuador, less than 0.074 to $32.33 \mathrm{~g} / 100 \mathrm{~g}$ from 67 species of stingless bee (Nordin et al. 2018), less than $0.074 \mathrm{mg} / \mathrm{L}$ for honey from ten species of stingless bees (Meliponinae) from Santa Catarina, Brazil (Biluca et al. 2016), 0.025 to $6.0 \mathrm{~g} / 100$ $\mathrm{g}$ for honey from 11 stingless bee species in Thailand (Chuttong et al. 2016).

The G/M ratio of honey is one of the critical parameters used to predict the crystallization process of honey. The higher glucose content and the lower moisture impact the rapid crystallization process in honey because their $\mathrm{F} / \mathrm{M}$ ratio is more significant. Honey with a G/M ratio under 1.7 is slower crystallization process and has no crystallization, but honey with a $\mathrm{G} / \mathrm{M}$ ratio of more than 2 is rapidly crystallization (Dobre et al. 2012). However, honey in our study has not crystallized, although it has been stored for 2 years. The G/M ratio of $T$. laeviceps honey (Figure 2) was different from previously reported by Agussalim et al. (2021) for the honey of $T$. laeviceps from different geographical origins in Indonesia (Sleman, Lombok, and Gunungkidul) is ranging from 0.50 to 1.17 and not crystalized despite has been stored for 2 years. In addition, also was differ with reported by Dobre et al. (2012) for several types of honey such as rape honey (1.4 to 2.9 ), multi-floral honey (1.3 to 2.0$)$, sun-flower honey (1.5 to 1.9 ), linden honey (1.3 to 2.4 ), and honeydew (1.2 to 1.9 ).

The F/G ratio is described the crystallization process in honey (Suntiparapop et al. 2012; Escuredo et al. 2014; Da Silva et al. 2016). In addition, the fructose to glucose ratio also has been recommended to evaluate the granulation or honey crystallization because the solubility of glucose in water is lower than fructose (De La Fuente et al. 2011; Dobre et al. 2012; Tornuk et al. 2013; Escuredo et al. 2014; Da Silva et al. 2016). The crystallization process in honey is related to the fructose and glucose contents, where the higher fructose content than glucose content may be honey has not crystalized. Furthermore, honey with a higher glucose content than fructose content may be crystalized (Escuredo et al. 2014; Da Silva et al. 2016). Honey with a higher glucose content and lower fructose to glucose ratio is rapidly crystallized. Still, the higher fructose to glucose ratio (containing less than $30 \%$ ) is relatively slow to reduce and still liquid for several years without the specific treatment (Dobre et al. 2012; Da Silva et al. 2016). Honey with an F/G ratio above 1.3 has a slower crystallization property than honey with a rapidly crystalized F/G ratio under 1 (Dobre et al. 2012; Da Silva et al. 2016).
The F/G ratio in our study (Figure 2) differs with the previous study by Agussalim et al. (2019a) for honey from $T$. laeviceps from different geographical origins in Indonesia (Sleman, Lombok, and Nglipar Gunungkidul) is ranges from 0.34 to 1.99 and is differ reported by Suntiparapop et al. (2012) for T. laeviceps honey from Thailand is ranging from 1.27 to 1.40 . Honey in our study has not crystallized and also similar with reported by Agussalim et al. (2019a) for honey from $T$. laeviceps has not crystallized, however, it has been stored for 2 years and its contrast with reported by Suntiparapop et al. (2012) that honey from T. laeviceps origin from Thailand is crystallized after stored for 1 year.

The $\mathrm{pH}$ value and acidity are used to evaluate honey quality and fresh honey level and related to antibacterial activity. The high edge and the low $\mathrm{pH}$ value indicate the honey fermentation process, which influenced the honey quality and organoleptic characteristics (Alvarez-Suarez et al. 2018). However, honey from the stingless bee has flavors such as sweet, sour, and bitter (Agussalim, 2020; Agussalim et al. 2021, 2019a). Furthermore, the $\mathrm{pH}$ value was used to verify the fake honey (honey manipulation) (Da Silva et al. 2016). For example, honey was added by corn syrup is impacted on the increasing the value of honey $\mathrm{pH}$ significantly than pure honey (Ribeiro et al. 2014). Furthermore, the $\mathrm{pH}$ value of honey was affected by nectar sources from plants, bee species, geographical origins, and the maturity level of honey ( $\mathrm{Da}$ Silva et al. 2016; Agussalim et al. 2021). The honey pH in our study (Figure 2) was differ with previously reported by Agussalim et al. (2021) for honey from T. laeviceps from different geographical origin from Indonesia (Sleman, Lombok, and Gunungkidul) is ranging from 3.85 to $4.14,3.1$ to 3.9 for honey from 11 stingless bee species in Thailand (Chuttong et al. 2016), 3.33 to 6.56 for honey from ten species of stingless bees (Meliponinae) from Santa Catarina, Brazil (Biluca et al. 2016), 3.2 to 6.64 from 67 species of stingless bee (Nordin et al. 2018), 3.08 to 3.58 for stingless bee honey from Ecuador (Villacrés-Granda et al. 2021). Thus, it can be concluded that the geographical origin influences the sugars profile of honey. Honey from Sleman has the highest sugars content, followed by the honey from Klaten, while honey from Gunungkidul has the least.

\section{ACKNOWLEDGEMENTS}

The authors would like to thank the Directorate of Research, Universitas Gadjah Mada, Yogyakarta, Indonesia for financial support of the research through Program Penelitian Kolaborasi Indonesia (PPKI 2021) grant collaboration with Hasanuddin University, Makassar, Indonesia and University of Indonesia, Depok, Indonesia.

\section{REFERENCES}

Agus A, Agussalim, Nurliyani, Umami N, Budisatria IGS. 2019. Evaluation of antioxidant activity, phenolic, flavonoid and vitamin $\mathrm{C}$ content of several honeys produced by the Indonesian stingless bee: Tetragonula laeviceps. Livest Res Rural Dev 31: 152. DOI: 10.1088/1755-1315/387/1/012084.

Agussalim. 2020. Domestication and Meliponiculture of Stingless Bee Tetragonula laeviceps: Evaluation of Production Potency and Honey 
Quality as an Immunomodulator. [Dissertation]. Universitas Gadjah Mada, Yogyakarta. [Indonesian].

Agussalim, Agus A, Nurliyani, Umami N. 2019a. The sugar content profile of honey produced by the Indonesian Stingless bee, Tetragonula laeviceps, from different regions. Livest Res Rural Dev 31: 91. DOI: 10.1088/1755$1315 / 387 / 1 / 012084$

Agussalim, Agus A, Nurliyani, Umami N. 2019b. Free amino acids profile of honey produced by the Indonesian stingless bee: Tetragonula laeviceps. In: The $8^{\text {th }}$ International Seminar on Tropical Animal Production. Faculty of Animal Science, Universitas Gadjah Mada, Yogyakarta, 23-25 September 2019. DOI: 10.1088/1755-1315/387/1/012084.

Agussalim, Agus A, Nurliyani, Umami N, Budisatria IGS. 2019c. Physicochemical properties of honey produced by the Indonesian stingless bee: Tetragonula laeviceps. IOP Conf Ser Earth Environ Sci 387: 012084. DOI: $10.1088 / 1755-1315 / 387 / 1 / 012084$.

Agussalim, Nurliyani, Umami N, Agus A. 2020. The honey and propolis production from Indonesian stingless bee: Tetragonula laeviceps. Livest Res Rural Dev 32: 121. DOI: 10.13057/biodiv/d220820.

Agussalim, Umami N, Nurliyani, Agus A. 2021. The physicochemical composition of honey from Indonesian stingless bee (Tetragonula laeviceps). Biodiversitas 22: 3257-3263. DOI: 10.13057/biodiv/d220820.

Alvarez-Suarez JM, Giampieri F, Brenciani A, Mazzoni L, Gasparrini M, González-Paramás AM, Santos-Buelga C, Morroni G, Simoni S, ForbesHernández TY, Afrin S, Giovanetti E, Battino M. 2018. Apis mellifera vs Melipona beecheii Cuban polifloral honeys: A comparison based on their physicochemical parameters, chemical composition and biological properties. LWT - Food Sci Technol 87: 272-279. DOI: 10.1016/j.lwt.2017.08.079

AOAC. 2005. Official Method of Association of Official Analytical Chemist. 18th Edition. Association of Official Analytical Chemist. Benjamin Franklin Station, Washington DC.

Biluca FC, Braghini F, Gonzaga LV, Costa ACO, Fett R. 2016. Physicochemical profiles, minerals and bioactive compounds of stingless bee honey (Meliponinae). J Food Compos Anal 50: 61-69. DOI: 10.1016/j.jfca.2016.05.007.

Bogdanov S, Lüllmann C, Martin P, von der Ohe W, Russmann H, Vorwohl G, Oddo LP, Sabatini AG, Marcazzan GL, Piro R, Flamini C, Morlot M, Lhéritier J, Borneck R, Marioleas P, Tsigouri A, Kerkvliet J, Ortiz A, Ivanov T, D’Arcy B, Mossel B, Vit P. 1999. Honey quality and international regulatory standards: Review by the international honey commission. Bee World 80: 61-69. DOI 10.1080/0005772x.1999.11099428.

Chanchao C. 2013. Bioactivity of Honey and Propolis of Tetragonula laeviceps in Thailand. In: Vit P, Pedro S, Roubik D (eds.). Pot-Honey: A Legacy of Stingless Bees. Springer, New York. DOI: 10.1007/978-14614-4960-7 36

Chuttong B, Chanbang Y, Sringarm K, Burgett M. 2016. Physicochemical profiles of stingless bee (Apidae: Meliponini) honey from South East Asia (Thailand). Food Chem 192: 149-155. DOI 10.1016/j.foodchem.2015.06.089.

Codex Alimentarius. 2001. Draft revised standard for standard for honey (at step 10 of the Codex procedure). Alinorm 01: 19-26.

Da Silva PM, Gauche C, Gonzaga LV, Costa ACO, Fett R. 2016. Honey: Chemical composition, stability and authenticity. Food Chem 196: 309323. DOI: $10.1016 /$ j.foodchem.2015.09.051.

De La Fuente E, Ruiz-Matute AI, Valencia-Barrera RM, Sanz J, Martínez Castro I. 2011. Carbohydrate composition of Spanish unifloral honeys. Food Chem 129: 1483-1489. DOI: 10.1016/j.foodchem.2011.05.121.

Dobre I, Georgescu LA, Alexe P, Escuredo O, Seijo MC. 2012. Rheological behavior of different honey types from Romania. Food Res Int 49: 126 132. DOI: 10.1016/j.foodres.2012.08.009.

Erwan, Astuti M, Syamsuhaidi Muhsinin M, Agussalim. 2020. The effect of different beehives on the activity of foragers, honey pots number and honey production from stingless bee Tetragonula sp. Livest Res Rural Dev 32: 158.

Erwan, Suhardin, Syamsuhaidi, Purnamasari DK, Muhsinin M, Agussalim. 2021. Propolis mixture production and foragers daily activity of stingless bee Tetragonula sp . in bamboo and box hives. Livest Res Rural Dev 33: 82

Escuredo O, Dobre I, Fernández-González M, Seijo MC. 2014. Contribution of botanical origin and sugar composition of honeys on the crystallization $\begin{array}{lllll}\text { phenomenon. Food Chem 149: 84-90. DOI: } & \end{array}$ 10.1016/j.foodchem.2013.10.097.
Escuredo O, Míguez M, Fernández-González M, Seijo MC. 2013. Nutritional value and antioxidant activity of honeys produced in a European Atlantic area. Food Chem 138: 851-856. DOI: 10.1016/j.foodchem.2012.11.015.

Fletcher MT, Hungerford NL, Webber D, Carpinelli de Jesus M, Zhang J, Stone ISJ, Blanchfield JT, Zawawi N. 2020. Stingless bee honey, a novel source of trehalulose: A biologically active disaccharide with health benefits. Sci Rep 10: 1-8. DOI: 10.1038/s41598-020-68940-0.

Guerrini A, Bruni R, Maietti S, Poli F, Rossi D, Paganetto G, Muzzoli M, Scalvenzi L, Sacchetti G. 2009. Ecuadorian stingless bee (Meliponinae) honey: A chemical and functional profile of an ancient health product. Food Chem 114: 1413-1420. DOI: 10.1016/j.foodchem.2008.11.023.

Juan-Borrás M, Domenech E, Hellebrandova M, Escriche I. 2014. Effect of country origin on physicochemical, sugar and volatile composition of acacia, sunflower and tilia honeys. Food Res Int 60: 86-94. DOI: 10.1016/j.foodres.2013.11.045.

Kahono S, Chantawannakul P, Engel MS. 2018. Social Bees and the Current Status of Beekeeping in Indonesia. In: Chantawannakul P, Williams G, Neumann P (eds.). Asian Beekeeping in the $21^{\text {st }}$ Century. Springer, Singapore. DOI: 10.1007/978-981-10-8222-1.

Kamal MA, Klein P. 2011. Determination of sugars in honey by liquid chromatography. Saudi J Biol Sci 18: 17-21. DOI: 10.1016/j.sjbs.2010.09.003.

Michener CD. 2013. The Meliponini. In: Patricia DV, Pedro SRM, Roubik DW (eds.). Pot - Honey: A Legacy of Stingless Bees. Springer, New York. DOI: 10.1007/978-1-4614-4960-7_1.

Nordin A, Sainik NQAV, Chowdhury SR, Saim AB, Idrus RBH. 2018. Physicochemical properties of stingless bee honey from around the globe: A comprehensive review. J Food Compos Anal 73: 91-102. DOI: 10.1016/j.jfca.2018.06.002.

Puscas A, Hosu A, Cimpoiu C. 2013. Application of a newly developed and validated high-performance thin-layer chromatographic method to control honey adulteration. J Chromatogr A 1272: 132-135. DOI: 10.1016/j.chroma.2012.11.064.

Ranneh Y, Ali F, Zarei M, Akim AM, Hamid HA, Khazaai H. 2018. Malaysian stingless bee and Tualang honeys: A comparative characterization of total antioxidant capacity and phenolic profile using liquid chromatography-mass spectrometry. LWT - Food Sci Technol 89: 1-9. DOI: 10.1016/j.lwt.2017.10.020.

Ribeiro RDOR, Mársico ET, Carneiro CDS, Monteiro MLG, Júnior CC, De Jesus EFO. 2014. Detection of honey adulteration of high fructose corn syrup by Low Field Nuclear Magnetic Resonance (LF 1H NMR). J Food Eng 135: 39-43. DOI: 10.1016/j.jfoodeng.2014.03.009.

Sabir A, Agus A, Sahlan M, Agussalim. 2021. The minerals content of honey from stingless bee Tetragonula laeviceps from different regions in Indonesia. Livest Res Rural Dev 33: 22.

SNI. 2018. Indonesian National Standard for Honey. Badan Standarisasi Nasional, Jakarta. [Indonesian]

Souza B, Roubik D, Barth O, Heard T, Enriquez E, Carvalho C, Villas-Boas J, Marchini L, Locatelli J, Persano-Oddo L, Almeida-Muradian L, Bogdanov S, Vit P. 2006. Composition of stingless bee honey: Setting quality standards. Interciencia 31: 867-875.

Suntiparapop K, Prapaipong P, Chantawannakul P. 2012. Chemical and biological properties of honey from Thai stingless bee (Tetragonula leaviceps). J Apic Res 51: 45-52. DOI: 10.3896/IBRA.1.51.1.06.

Thrasyvoulou A, Tananaki C, Goras G, Karazafiris E, Dimou M, Liolios V, Kanelis D, Gounari S. 2018. Legislation of honey criteria and standards. J Apic Res 57: 88-96. DOI: 10.1080/00218839.2017.1411181.

Tornuk F, Karaman S, Ozturk I, Toker OS, Tastemur B, Sagdic O, Dogan M, Kayacier A. 2013. Quality characterization of artisanal and retail Turkish blossom honeys: Determination of physicochemical, microbiological, bioactive properties and aroma profile. Ind Crops Prod 46: 124-131. DOI: 10.1016/j.indcrop.2012.12.042.

Trianto M, Purwanto H. 2020. Morphological characteristics and morphometrics of stingless bees (Hymenoptera: Meliponini) in Yogyakarta, Indonesia. Biodiversitas 21: 2619-2628. DOI: 10.13057/biodiv/d210633.

Villacrés-Granda I, Coello D, Proaño A, Ballesteros I, Roubik DW, Jijón G, Granda-Albuja G, Granda-Albuja S, Abreu-Naranjo R, Maza F, Tejera E, González-Paramás AM, Bullón P, Alvarez-Suarez JM. 2021. Honey quality parameters, chemical composition and antimicrobial activity in twelve Ecuadorian stingless bees (Apidae: Apinae: Meliponini) tested against multiresistant human pathogens. LWT-Food Sci Technol 140: 110737. DOI: $10.1016 /$ j.lwt.2020.110737. 